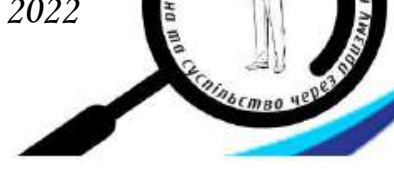

УДК 373.3.04:316.61

https://doi.org/10.52058/2786-5274-2022-1(3)-275-282

Партола Вікторія Вікторівна кандидат педагогічних наук,доцент кафедри теорії і методики викладання природничо-математичних дисциплін у дошкільній, початковій i спеціальній освітіг. Харківський національний педагогічний університет імені Г.С. Сковороди, вул. Валентинівська, 2, м. Харків, 61168, https://orcid.org/0000-0002-2575-9692

Смолянюк Наталя Миколаӥвна кандидат педагогічних наук, доцент кафедри теорії і методики викладання природничо-математичних дисциплін у дошкільній, початковій і спеціальній освіті, Харківський національний педагогічний університет імені Г.С. Сковороди, вул. Валентинівська, 2, Харків, 61168, https://orcid.org/ 00000003-3524-581X

Білецька Світлана Анатоліївна кандидат педагогічних наук, доцент кафедри теорії і методики викладання природничо-математичних дисциплін у дошкільній, початковій і спеціальній освіті, Харківський національний педагогічний університет імені Г.С. Сковороди, вул. Валентинівська, 2, Харків, 61168, https://orcid.org/0000-0002-3354-2629

\title{
АНАЛІЗ ФОРМУВАННЯ ІНКЛЮЗИВНОЇ КОМПЕТЕНТНОСТІ У МАЙБУТНІХ УЧИТЕЛІВ ПОЧАТКОВИХ КЛАСІВ (ДОСВЦД ХАРКІВСЬКОГО НАЦІОНАЛЬНОГО ПЕДАГОГІЧНОГО УНІВЕРСИТЕТУ ІМЕНІ Г.С. СКОВОРОДИ)
}

Анотація. У статті розкрито питання формування у майбутніх учителів початкових класів інклюзивної компетентності 3 досвіду роботи факультету початкового навчання Харківського національного педагогічного університету Г.С.Сковороди. Надано визначення понять «інклюзія», «інклюзивна освіта», «інтеграція». Схарактеризовано модель формування інклюзивної компетентності у майбутнього вчителя початкових класів на факультеті початкового навчання Харківського Національного педагогічного університету імені Г.С. Сковороди. З'ясовано, що під час навчання в університеті, зокрема, питання інклюзивного навчання порушено у таких навчальних дисциплінах, як: Організація корекційнореабілітаційної діяльності; Спеціальна (корекційна) педагогіка; Організація здоров'язбережувального середовища у початковій школі та інші.

В інклюзивній компетентності майбутніх вчителів початкових класів особливого значення набувають предмети Методики 3 спеціальними методиками навчання: Методика навчання української мови зі спеціальними методиками та каліграфія, Методика навчання мови у школах національних 
меншин зі спеціальними методиками, Методика навчання освітньої галузі «Математика» зі спеціальними методиками, Методика навчання предмету «Я досліджую світ» зі спеціальними методиками, Фізичне виховання 3 методикою навчання зі спеціальними методиками, Методика навчання мистецьких дисциплін (Образотворче мистецтво. Музичне виховання. Хореографія) зі спеціальними методиками, Методика навчання мистецьких дисциплін (Образотворче мистецтво. Музичне виховання. Хореографія) зі спеціальними методиками, Дизайн i технології 3 методикою навчання та спеціальними методиками тощо. Важливу роль в формуванні інклюзивної компетентності здобувачів факультету початкового навчання ХНПУ ім. Г.С. Сковороди відіграють педагогічні практики у закладах загальної та спеціальної освіти, Педагогічний проєкт «Школа професійного зростання «День у школі», залучення до волонтерської діяльності. Беззаперечно позитивний результат має наукова діяльності здобувачів, що здійснюється під керівництвом викладачів кафедр (курсові роботи, кваліфікаційні наукові роботи магістрів доповіді для виступу на науково-практичних конференціях з подальшою публікацією та інше.

Ключові слова: інклюзивна компетентність, майбутні вчителі, досвід роботи.

Partola Victoriia Viktorivna Ph.D. (Pedagogics), Associate Professor,Department of Theory and Methodics of Teaching Natural-Mathematical Disciplines in Preschool, Primary and Special EducationH. S. Skovoroda Kharkiv National Pedagogical University, Valentinovskaya St., 2, Kharkiv, 61168, https://orcid.org/0000-0002-2575-9692

Smolianiuk Natalia Mykolaivna Ph.D. (Pedagogics), Associate Professor,Department of Theory and Methodics of Teaching Natural-Mathematical Disciplines in Preschool, Primary and Special Education H. S. Skovoroda Kharkiv National Pedagogical University, Valentinovskaya St., 2, Kharkiv, 61168, https://orcid.org/00000003-3524-581X

Biletska Svitlana Anatoliivna Ph.D. (Pedagogics), Associate Professor,Department of Theory and Methodics of Teaching Natural-Mathematical Disciplines in Preschool, Primary and Special Education H. S. Skovoroda Kharkiv National Pedagogical University, Valentinovskaya St., 2, Kharkiv, 61168, https://orcid.org/0000-0002-3354-2629

\section{ANALYSIS OF FORMATION OF INCLUSIVE COMPETENCE IN FUTURE PRIMARY TEACHERS (EXPERIENCE OF KHARKIV NATOINAL PEDAGOGICAL UNIVERSITY NAMED)}

Abstract. The article reveals the issue of formation of inclusive competence in future primary school teachers from the experience of the Faculty of Primary 
Education of Kharkiv National Pedagogical University GS Skovoroda. The definitions of "inclusion", "inclusive education", "integration" are given. The model of formation of inclusive competence in the future primary school teacher at the faculty of primary education of Kharkiv National Pedagogical University named after G.S. Frying pans. It was found that while studying at the university, in particular, the issue of inclusive education was raised in such disciplines as: Organization of correctional and rehabilitation activities; Special (correctional) pedagogy; Organization of a healthy environment in primary school and others.

In the inclusive competence of future primary school teachers of special importance are the subjects Methods with special teaching methods: Methods of teaching Ukrainian with special methods and calligraphy, Methods of teaching languages in schools of national minorities with special methods, Methods of teaching "Mathematics" with special methods, Methods teaching the subject "I explore the world" with special techniques, Physical education with teaching methods with special techniques, Methods of teaching art disciplines (Fine Arts. Music education. Choreography) with special techniques, Methods of teaching art disciplines (Fine Arts. Music education. Choreography) with special techniques, Design and technology with teaching methods and special techniques and more. An important role in the formation of inclusive competence of students of the Faculty of Primary Education KhNPU. G.S. Frying pans play pedagogical practices in general and special education institutions, Pedagogical project "School of professional growth" Day at school ", involvement in volunteering. Undoubtedly, the scientific activity of the applicants has a positive result, which is carried out under the guidance of teachers of departments (term papers, qualifying research papers of masters reports for presentation at scientific and practical conferences with subsequent publication and more.

Keywords: inclusive competence, future teachers, work experience.

Постановка проблеми. Демократичні перетворення, що відбуваються в Україні, процес входження у європейську спільноту зумовили зміну ставлення суспільства до проблем людей 3 обмеженими можливостями здоров'я, призвели до усвідомлення необхідності їх ширшої інтеграції у соціум. У шкільній освіті це втілилося у розробку низки концептуальних положень щодо забезпечення рівних прав та можливостей в отриманні освітніх послуг дітьми 3 обмеженими можливостями здоров'я у загальноосвітніх закладах освіти. Перш за все це визнання Україною у 1991 році Конвенції ООН «Про права дитини», де зазначено «...усі діти мають право на освіту, i, як наслідок цього права, на прогрес» Підхід «школа всім» було викладено у Саламанській декларації, прийнятої 1994 року 92 країнами і 25 організаціями у співпраці з ЮНЕСКО. Положення цієї Декларації імплементувалося в національне законодавство України як члена ЮНЕСКО. У цьому документі пріоритетним завданням освітньої політики було оголошено створення освіти. 
Ще донедавна (до середини 90-х років XX століття) навчання дітей з ООП здійснювалося переважно в школах-інтернатах, що призводить до соціальної ізоляції цих дітей та усунення батьків від їхнього виховання. Внаслідок цього випускники навчальних закладів інтернатного типу зазнають труднощів подальшої інтеграції в соціум. Водночас багато дітей, які перебувають під патронатом системи спеціальної освіти, можуть навчатися у загальноосвітніх навчальних закладах. Враховуючи загальносвітовий підхід до навчання дітей 3 обмеженими можливостями здоров'я разом 3 однолітками, що нормально розвиваються, в Україні в останні роки посилюється процес їх інтеграції та включення в загальноосвітнє середовище.

Юнеско розглядає інклюзію як підхід, що «динамічно розвивається, полягає в позитивному відношенні до різноманітності учнів і в сприйнятті індивідуальних особливостей не як проблеми, а як можливості для збагачення процесу пізнання ».

Інклюзія - це процес збільшення ступеня участі всіх громадян у соціальному житті. Це політика й процес, що дає можливість усім дітям брати участь у всіх програмах. Інклюзивна освіта - це система освітніх послуг, що грунтується на принципі забезпечення основного права дітей на освіту та права навчатися за місцем проживання, що передбачає навчання дитини 3 особливими освітніми, зокрема дитини 3 особливостями психофізичного розвитку, в умовах загальноосвітнього закладу [3 ].

Інтеграція - зусилля, спрямовані на введення дітей 3 особливими освітніми потребами в регулярний освітній простір, пристосування учня до вимог школи. Процес інтеграції можна вважати проміжним етапом розвитку інклюзивної системи освіти [1].

Аналіз останніх досліджень i публікацій. Питання підготовки, готовності та неготовності педагогів до роботи в умовах інклюзивного навчання порушено у роботах сучасних українських науковців (К.Гудзь, Л.Коврігіна, Н.Лалак, З.Удич).

Ю.Бойчук, О.Бородіна, А.Гончаренко, Л.Кальченко, С.Наход, Н.Фіголь та інші наголошують, що результатом відповідної підготовки майбутнього педагога буде сформована інклюзивна компетентність, яка включає мотиваційний, когнітивний, операційний та рефлексивний компоненти.

Мета статті: розкрити досвід формування інклюзивної компетентності у майбутніх учителів початкових класів на факультеті початкового навчання Харківського національного педагогічного університету.

Виклад основного матеріалу. Широке впровадження ідей інтеграції та інклюзії у загальноосвітні заклади України значною мірою залежить від кваліфікації кадрів, що вимагає внесення змін до процесу підготовки майбутніх вчителів. I в цьому ракурсі особливого значення набуває проблема формування інклюзивної компетентності майбутніх вчителів як складової професійної компетентності. 
У даний час у вітчизняній педагогіці склався компетентностний підхід у сфері загальної та професійної освіти. Компетентнісний підхід як мета i результати навчання визначає формування ключових компетенцій різного рівня, що виражаються надалі у професійній діяльності як компетентність. Так, професійний стандарт вчителя початкових класів втілює сучасний підхід до визначення переліку та опису загальних і професійних компетентностей вчителя, до яких увійшла i інклюзивна компетентність. Інклюзивна компетентність вчителя початкових класів полягає в здатності створювати умови, що забезпечують функціонування інклюзивного освітнього середовища; здатність до педагогічної підтримки осіб з особливим освітніми потребами; здатність забезпечувати в освітньому середовищі сприятливі умови для кожного учня, залежно від його індивідуальних потреб, можливостей, здібностей і інтересів [2].

У Харківському національному педагогічному університеті імені Г.С. Сковороди на факультеті початкового навчання освітній процес організовано таким чином, щоб максимально задовольняти усі вимоги до сучасного освітнього середовища та відповідати Професійному стандарту «Вчителя початкових класів закладу загальної середньої освіти» та «Вчителя 3 загальної середньої освіти». Належна увага приділяється підготовці майбутнього вчителя до роботи в інклюзивному середовищі.

Саме тому на факультеті було впроваджено кілька освітніх програм. Серед яких: «Початкова освіта», «Початкова освіта з методиками спеціальної освіти», «Початкова освіта. Артпедагогіка», «Початкова освіта. Лікувальна педагогіка».

До змісту освітніх програм увійшли такі дисципліни за вибором: Організація корекційно-реабілітаційної діяльності; Спеціальна (корекційна) педагогіка; Організація здоров'язбережувального середовища у початковій школі та інші.

Блок методичних дисциплін включає спеціальні методики навчання: Методика навчання української мови зі спеціальними методиками та каліграфія, Методика навчання мови у школах національних меншин зі спеціальними методиками, Методика навчання освітньої галузі «Математика» зі спеціальними методиками, Методика навчання предмету «Я досліджую світ» зі спеціальними методиками, Фізичне виховання 3 методикою навчання зі спеціальними методиками, Методика навчання мистецьких дисциплін (Образотворче мистецтво. Музичне виховання. Хореографія) з спеціальними методиками, Методика навчання мистецьких дисциплін (Образотворче мистецтво. Музичне виховання. Хореографія) зі спеціальними методиками, Дизайн і технології з методикою навчання та спеціальними методиками. Усі вони спрямовані на формування інклюзивної компетентності майбутніх учителів початкової школи.

Під керівництвом доцентів та професорів факультету початкового навчання студенти активно займаються науковою діяльністю. Крім роботи над курсовими проєктами та магістерськими дослідженнями, здобувачі першого та 
другого освітніх рівнів $є$ учасниками всеукраїнських та міжнародних конференцій, авторами та співавторами наукових статей у різних виданнях (у тому числі і фахових). Як показує досвід, за останні 5 років, щонайменше десять відтоків від загальної кількості наукових робіт, виступів та публікацій були присвячені саме проблемам інклюзивної освіти.

Освітньою програмою передбачено щорічні педагогічні практики у закладах загальної середньої освіти та спеціалізованої середньої освіти.

Педагогічна практика для студентів починається вже на першому курсі та триває дванадцять тижнів. На другому та третьому курсах студенти йдуть на короткотривалу безперервну педагогічну практику. На третьому та четвертому курсах проходять практику у закладах загальної середньої освіти та спеціалізованої середньої освіти.

Для студентів кожного курсу перед практикою викладачі розробляють відповідні завдання. Серед таких них, обов'язково, є завдання направленні на формування інклюзивної компетентності майбутнього вчителя початкових класів. Тобто вже під час першої пасивної практики студенти готуються працювати в інклюзивному середовищі.

Нажаль, жодна з програм практики не передбачає і не дозволяє (через обмеження у часі ) виконання великого об'єму та різноманітності завдань.

Однак, враховуючи доцільність та необхідність їх виконання саме під час практики, деканом факультету Т. Довженко було прийнято рішення запровадити Педагогічний експеримент Школа професійного зростання «День у школі»[5]. Відповідно до змісту експерименту, починаючи з першого курсу один день на тиждень студенти факультету проводять у школі. В залежності від курсу, за ними закріплено методистів, викладачів педагогіки або тьютерів (здобувачів факультету другого освітнього рівня).

Програма безперервної педагогічної практики на першому курсі була поєднана 3 «Днем у школі». Саме тому іiі тривалість склала дванадцять тижнів i дозволила реалізувати низку завдань.

Для кожного курсу студентів до «Дня у школі» методисти різних дисциплін, педагогіки та психології розробляють чіткий перелік завдань. Частіше за все - це завдання, які неможливо було виконати у межах запланованої педагогічної практики, але можна реалізувати у рамках «Дня у школі».

Це стосується і згаданих завдань, щодо формування інклюзивної компетентності студентів. Такими завданнями можуть бути як ведення щоденника психолого-педагогічного спостереження за учнем 3 інвалідністю, індивідуальна робота 3 дитиною 3 особливими освітніми потребами так і інтерв’ювання учасників команди психолого-педагогічного супроводу дитини, участь у засіданні команди та інші.

Викладачами було здійснено аналіз та узагальнено проміжні результати педагогічного експерименту на факультеті початкового навчання. Слід 
відзначити, що усі показники за визначеними попередньо критеріями помітно зросли. Окрім значного підвищення рівня методичної компетентності студентів, збільшились показники інклюзивної компетентності на усіх курсах.

Студенти факультету початкового навчання щорічно активно долучаються до волонтерської діяльності. Окрім організації благодійних ярмарків 3 метою збору коштів для допомоги військовим, безпритульним тваринам, важкохворим дітям та ін. майбутні учителі початкових класів проводять святкові заходи у сиротинцях та дитячих будинках-інтернатах. Саме під час участі у подібних закладах їм часто доводиться працювати 3 дітьми 3 особливими освітніми потребами. 3 одного боку це потребує неабиякої підготовки 3 іншого сприяє швидшому формуванню інклюзивної компетентності студентів.

Висновки. Проаналізований нами зміст освітніх програм, діючих на факультеті початкового навчання ХНПУ ім. Г.С. Сковороди i напрямів формування інклюзивної компетентності майбутнього вчителя початкової школи дає підстави стверджувати, що освітня стратегія факультету початкового навчання Харківського національного педагогічного університету імені Г.С. Сковороди повністю відповідає формуванню інклюзивної компетентності студентів визначеної Професійним стандартом вчителя початкових класів.

\section{Лimepamypa:}

1. Нижник О. Допомога дітям з особливими потребами: Психолог. Київ, 2004. 123 с.

2. Професійний стандарт вчителя початкових класів https://mon.gov.ua/ua/news/ zatverdzheno-profstandart-vchitelya-pochatkovih-klasiv-vchitelya-zakladu-zagalnoyi-serednoyiosviti-i-vchitelya-z-pochatkovoyi-osviti.

3. Собчик Л. Н. Психология индивидуальности. Теория и практика психодиагностики. 2003. СПб. 624 с.

4. Софій Н., Найда Ю., Концептуальні аспекти інклюзивної освіти. Інклюзивна школа: особливості організації та управління: навчально-методичний посібник. К., 2007. 128 с.

5. Tytarenko L. I., Masiuk O. M., Smolyanyuk N. M. Pedagogical project "School of professional growth: A day at school" one of the ways of forming methodical competence of students. Theory and Practice of Future Teacher's Training for Work in New Ukrainian School : monograph. Prague, OKTAN PRINT s.r.o., 2020. P.463-474.

\section{References:}

1. Nyzhnyk O. (2004) Dopomoha ditiam z osoblyvymy potrebamy: Psykholoh [Helping children with special needs:Psychologist]. Kyiv.. [in Ukrainian].

2. Profesiinyi standart vchytelia pochatkovykh klasiv [Professional standard of a primary school teacher]. (n.d.). mon.gov.ua. Retrieved from https://mon.gov.ua/ua/news/zatverdzhenoprofstandart-vchitelya-pochatkovih-klasiv-vchitelya-zakladu-zagalnoyi-serednoyi-osviti-ivchitelya-z-pochatkovoyi-osviti. [in Ukrainian].

3. Sobchik L. N. (2003) Psihologiya individualnosti. [Psychology of personality] Teoriya i praktika psihodiagnostiki [Theory and practice of psychodiagnostics] SPb.[in Russian]. 
4. Sofii N., Naida Yu.(2007) Kontseptualni aspekty inkliuzyvnoi osvity. Inkliuzyvna shkola: osoblyvosti orhanizatsii ta upravlinnia [Conceptual aspects of inclusive education. Inclusive school: features of organization and management] navchalno-metodychnyi posibnyk. Kiev. [in Ukrainian].

5. Tytarenko L. I., Masiuk O. M., Smolyanyuk N. M. Pedagogical project "School of professional growth: A day at school" one of the ways of forming methodical competence of students. Theory and Practice of Future Teacher's Training for Work in New Ukrainian School : monograph. Prague, OKTAN PRINT s.r.o., 2020. P.463-474. [in English] 